\title{
NEW RECORDS AND DISTRIBUTION OF SPECIES FROM GENUS ARCTOPHILA SCHINER, 1860 (DIPTERA: SYRPHIDAE: ERISTALINAE) IN SERBIA
}

\author{
Mihailo Vujić*, Ivan Tot, Milan Đurić \\ HabiProt, Cankareva 9/13, 21000 Novi Sad, Serbia \\ *Corresponding author; E-mail: mihailovujic01@ gmail.com \\ (Received January 23, 2020, Accepted February 26, 2020)
}

\begin{abstract}
The genus Arctophila comprises large, bumblebee-like species of hoverflies (Diptera: Syrphidae). In Europe occur three species from this genus: A. bequaerti, A. bombiforme and A. superbiens and all of them were recorded in Serbia. Species from this genus were registered only on few mountains in Serbia and are considered rare in the country. During a survey conducted in 2018 and 2019, all three species were registered at several localities. The new findings of these species, photographs, maps of distribution and flight period diagram are presented in this paper. The descriptions of localities and observations related to the ecology of the species are also presented.
\end{abstract}

Keywords: Hoverflies, Arctophila bombiforme, A. bequaerti, A. superbiens, fauna, Vlasina

\section{INTRODUCTION}

Hoverflies (Syrphidae) are one of the most species-rich families of Diptera, with over 6000 described species belonging to 188 genera (THOMPSON, 2013). In Europe occur about 870 species, while the hoverfly fauna list in Serbia contains 412 species (SPEIGHT, 2016; VuJIĆ et $a l ., 2018)$. This family is widespread in the world and is an ecologically important group of insects that perform ecosystem services, like plant pollination, predation of plant pests and nutrient recycling (ROTHERAY and GILBERT, 2011).

Genus Arctophila Schiner, 1860 contains large robust bumblebee-mimic flies with long hairs on thorax and abdomen. The wing contains characteristic wedge-shaped dark spot in the middle, arista is feathered with long hairs and face is extended downwards so it forms a conical snout. Species from this genus may be confused with other bumblebee-like syrphids like Pocota Le Peletier \& Serville, 1828 and Criorhina Meigen, 1822 (though they have bare arista) or Volucella Geoffroy, 1762 (with closed R1 vein on the wing) (VAN VEEN, 2004). Some authors include this genus in genus Sericomyia Meigen, 1803, together with Conosyrphus Frey, 1915. In Europe 3 species from genus Arctophila can be found: A. bequaerti Hervé-Bazin, 1913, A. bombiforme (Fallén, 1810) and A. superbiens (Müller, 1776). A. bequaerti is so far in Europe known only from the southeast (Balkan Peninsula, Turkey and Caucasus) while in Serbia it has been discovered recently (SPEIGHT, 2015; VuJIĆ et al., 2016). A. bombiforme and A. superbiens 
are widespread species in Europe but their range is mostly restricted to mountainous areas (SPEIGHT, 2015).

\section{MATERIAL AND METHODS}

Field surveys were conducted during 2018 and 2019 at several localities in Serbia (Table 1.). Specimens were observed and caught by the entomological net and prepared by standard procedure. The identification of specimens was based on morphological characters and performed with the use of key SPEIGHT and SARTHOU (2017). The exact coordinates and altitudes were recorded on the spot using GPS devices, and all the data were systematized in our database Alciphron (http://alciphron.habiprot.org.rs/), after field surveys. The maps of distribution were made using QGIS 2.18 (www.qgis.org). The collected material is deposited in the private collection of the first author and at the Department of Biology and Ecology, University of Novi Sad (FSUNS).

Table 1. A list of studied localities.

\begin{tabular}{|l|c|c|}
\hline \multicolumn{1}{|c|}{ Locality } & Coordinates & Altitude (m) \\
\hline Đerekare, Bijela Voda & 42.97756620 .10404 & 1546 \\
\hline Đerekare, Stari Krst & 42.98513420 .117226 & 1450 \\
\hline Jadovnik, Mali Jadovnik & 43.30601619 .773967 & 1501 \\
\hline Jadovnik, Ogrljača 1 & 43.30879219 .765884 & 1480 \\
\hline Jadovnik, Ogrljača 2 & 43.31498519 .76571 & 1400 \\
\hline Vlasina, Cvejina dolina & 42.73973822 .297523 & 1411 \\
\hline Vlasina, Dejanova reka & 42.6546522 .381875 & 1242 \\
\hline Vlasina, Gadžini & 42.74894522 .306708 & 1369 \\
\hline Vlasina, Jančin potok & 42.7235222 .323433 & 1315 \\
\hline Vlasina, Jančini & 42.72200222 .323132 & 1335 \\
\hline Vlasina, Mali Čemernik & 42.74761322 .263256 & 1531 \\
\hline Vlasina, Plavilo 1 & 42.72960822 .28864 & 1494 \\
\hline Vlasina, Plavilo 2 & 42.73203722 .290498 & 1475 \\
\hline Vlasina Polom & 42.76099522 .327713 & 1238 \\
\hline Vlasina, Srednja reka & 42.75045822 .29165 & 1361 \\
\hline Vlasina, Taraija & 42.7419122 .342627 & 1270 \\
\hline Vlasina, Teskovo & 42.77919122 .312479 & 1227 \\
\hline Vlasina, Veliki Čemernik & 42.72888522 .28165 & 1545 \\
\hline Vlasina, Vlasina Rid & 42.72546722 .326393 & 1309 \\
\hline
\end{tabular}

\section{Description of localities}

Đerekare is a place in the western part of Serbia, between Pešter plateau and the border with Montenegro. Dominant forests are of beech (Fagus sp.), spruce (Picea abies (L.) H.Karst.), silver fir (Abies alba Mill.) with some mountainous grasslands. Quite a lot of cattle can be found in the area, especially cows.

Locality Bijela Voda is montane grassland, close to a beech-evergreen forest and with abundant livestock. The most numerous plants are Poaceae, Veratrum sp., Gentiana lutea L. and Parnassia palustris L.

Locality Stari Krst is situated next to the road, in the spruce-silver fir forest. A stream is flowing nearby, and dominant plants are Vaccinium myrtillus L., Rubus idaeus L., Sambucus racemosa $\mathrm{L}$. and Cirsium $\mathrm{sp}$. 
Jadovnik is a mountain in the southwestern part of Serbia, on the western edge of Pešter plateau, close to the town of Prijepolje. On mountain slopes dominant are forests of beech, spruce and fir, while higher parts are covered with meadows and pastures with shrubs of Juniperus communis L., Rubus idaeus L., Ribes sp. and Chamaecytisus sp. (MARKOVIĆ, 1990). In many places was evident intensive logging that can destroy pristine habitats and endanger the survival of lignicolous organisms.

Locality Mali Jadovnik is subalpine grassland surrounded by evergreen forests with dominant plants of the Asteraceae family (Cirsium sp., Centaurea sp., Carduus sp) and shrubs of Juniperus communis L.and Rubus idaeus L.

Localities Ogrljača 1 (Fig 1. D) and Ogrljača 2 (Fig 1. E) are localities in the beechevergreen forest where dominant plants next to the road were Mentha sp., Centaurea sp., Cirsium sp., Veratrum nigrum L. and Poaceae.

The plateau of Vlasina is in the southeastern Serbia, close to the border of Bulgaria. The lowest altitude at Vlasina is around $1200 \mathrm{~m}$ a.s.1., making this area one of the widest and highest plateaus in the country. The area is surrounded by mountains that belong to the Rhodope Massif: Vardenik, Čemernik, Gramada (Plana) and Bukova Glava (STANKOVIĆ and LAUŠEvić, 1997; RANĐELOVIĆ and ZLATKOVIĆ, 2010). Vlasina is a water-rich area with many small springs, streams and rivers. Extensive hydro technical interventions caused the formation of Vlasina Lake (BELIJ et al., 2014), located in the center of the area. Geology and water caused the forming of acid soils. This is a zone of dystric brown forest soil, which develops in mountainous regions within a beech forest zone but is nowadays mostly eroded and covered by grassy vegetation. Inside of this zone, eugley and dystric cambisol (swamp) soil types are also present (RANĐELOVIĆ and ZLATKOVIĆ, 2010). Zonal beech forests are very fragmented nowadays and have been replaced by dry grassland vegetation due to strong anthropogenic pressure in the past. Other major vegetation types include silver birch (Betula pendula Roth) forests, developing as a succession stage and hygrophilous vegetation communities along streams and the lake itself (RANĐELOVIĆ and ZLATKOVIĆ, 2010).

Localities Cvejina Dolina and Srednja Reka are situated in a valley between beech forests, near to the confluence of Plavilo river into Cvejina Reka river and along the course of the Srednja Reka river. In vicinity, dominant are beech forests, shrubs such as Rubus idaeus and Vaccinium myrtillus L., umbellifers, composites and Filipendula sp.

Locality Dejanova Reka is situated next to the road where beech forests and fragmented mires are present. Dominant are plants that prefer mires and wetlands: Succisa pratensis Moench, Epipactis palustris (L.) Crantz, Equisetum sp. and Salix sp.

Locality Gadžini is situated next to the road in the beech-birch forest. Present are numerous shrubs of Vaccinium myrtillus L.

Locality Jančin Potok is located next to the road, on the beech forest edge and dominant plants are Epilobium angustifolium L. and Rubus idaeus L.

Locality Jančini is situated next to the road, between Pinus sylvestris L. forest and beech-birch forest.

Locality Mali Čemernik is situated in the beech forest on Čemernik mountain. Present are little puddles and numerous rotten beech trunks.

Localities Plavilo 1 and Plavilo 2 are situated next to the Plavilo river on the Čemernik mountain. The river is surrounded by flooded meadows overgrown with Polygonum bistorta L., Filipendula sp., Potentilla sp., Valeriana officinalis L. and spruce forest. In the forest present are springs, puddles and semi-liquid mud that may be a habitat for larval development.

Locality Polom is a place in the beech-birch forest where concrete pipes were laid for transferring water from Polomska Reka river to Vlasina Lake accumulation. In this site a very pronounced anthropogenic influence is evident. 
Locality Taraija is the edge of willow forest with a spring. In the surrounding area also present are forests of pine, spruce and birch.

Locality Teskovo is situated near Vlasina River, on the edge of a willow forest. The most numerous plants by the river are Mentha sp. and Scabiosa sp.

Locality Veliki Čemernik is situated on Čemernik mountain, along the course of a stream winding through coniferous forest. Quite a lot of cattle use it for pasture and water in stream is contaminated with cow feces. Stream shores are overgrown with Vaccinium myrtillus L., Chamaecytisus sp. and Polygonum bistorta L.

Locality Vlasina Rid is a settlement above Vlasina Lake. There are many private houses, few streams and beech-birch forests.

The entomofauna of Vlasina has been actively researched for the past few years (Lepidoptera, Odonata, Orthoptera, Hemiptera, Diptera: Syrphidae). Results indicate there are many rare, endangered, endemic and relict species in the region (PAVIĆEVIĆ et al., 2014; SKEJO and IVković, 2015; Tot et al., 2015; VuJiĆ et al., 2016; ŠEAT, 2017; ToT et al., 2017; TOT et al., 2018; ĐUKIĆ et al., 2019; PROTIĆ and NADAŽDIN, 2019).

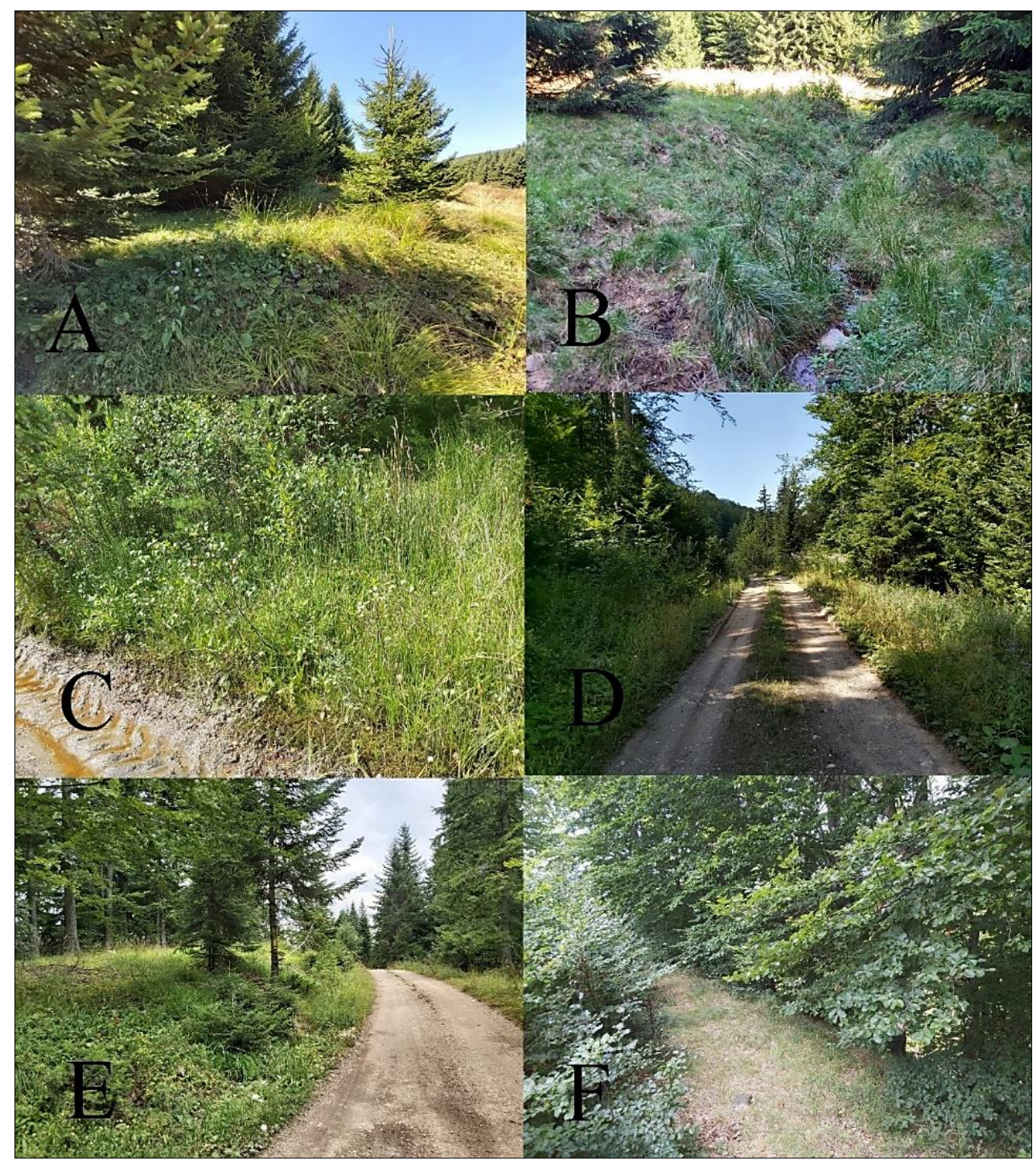

Figure 1. Localities where Arctophila species have been observed and collected; A) Vlasina, Plavilo 1;

B) Vlasina, Veliki Čemernik; C) Vlasina, Dejanova reka; D) Jadovnik, Ogrljača 1;

E) Jadovnik, Ogrljača 2; F) Karamanica, locality bumblebee-like syrphid resembling Arctophila bombiforme was observed (photos by M. Vujić, 2018-2019). 


\section{RESULTS AND DISCUSSION}

Altogether 41 specimens of all three Arctophila species occuring in Serbia and Europe were collected - A. bequaerti, A. bombiforme and A. superbiens.

\section{Arctophila bequaerti Hervé-Bazin, 1913 (Figs. 2A, 3A)}

Published records: VuJIĆ et al. (2016).

New records: Vlasina: Dejanova reka, 16.8.2019., 1ð, leg. M. Vujić; 2.9.2019., 1 \&, leg.

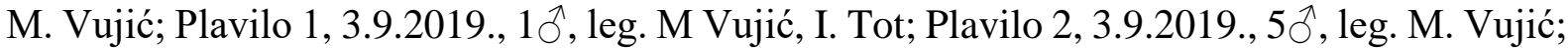
Jančin potok, 5.9.2019., 1§̂, leg. M. Vujić

Notes: A. bequaerti is a recently discovered species in Serbia and its ecology is not well known (VUJIĆ et al. 2016). This species is present in Turkey, southern Russia, Ukraine, Armenia and in the Balkan Peninsula (Albania, Greece, Bulgaria and certain parts of former Yugoslavia) (SPEIGHT, 2015). In Serbia A. bequaerti was registred only at Vlasina plateau, where it inhabits wetlands and marshes by the roads or forest edges and can be found together with A. bombiforme on localities Dejanova reka, Jančin potok, Plavilo 1, Plavilo 2 and Vlasina Rid. Specimens of both species were most numerous at localities Plavilo 1 and Plavilo 2. Adults were observed feeding on flowers of Succisa pratensis Moench, Scabiosa sp. and Gentiana asclepiadea L.

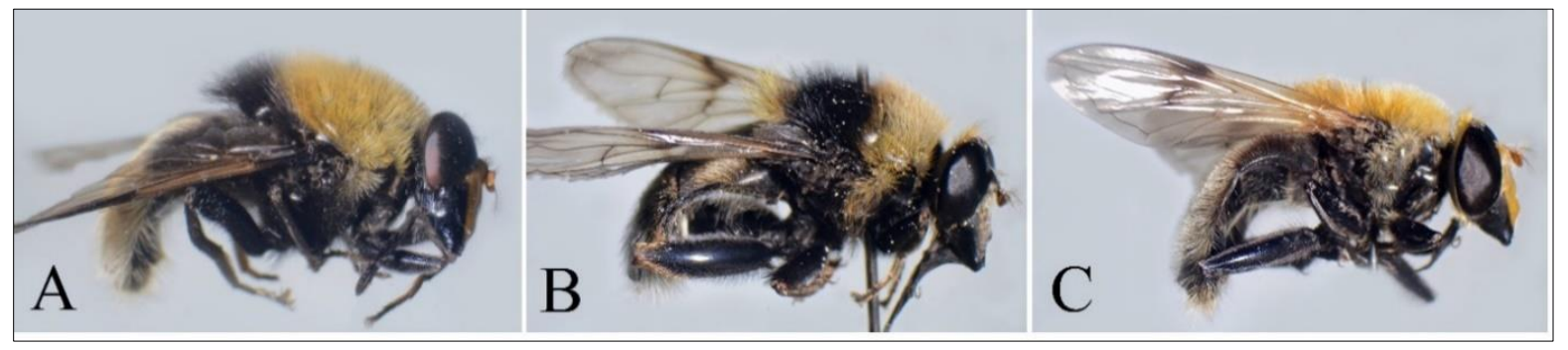

Figure 2. The habitus of species from genus Arctophila; A) A. bequaerti; B) A. bombiforme; C) A. superbiens (photos by T. Tot, 2019)

Arctophila bombiforme (Fallén, 1810) (Figs. 2B, 3B)

Published records: GlumaC (1955); RADENKOVIĆ (2008); RADENKOVIĆ et al. (2013); MiLIČIĆ et al. (2018).

New records: Đerekare: Bijela Voda, 31.7.2019., 1ð, leg. M. Vujić; Stari Krst, 31.7.2019., $1 \delta^{\Uparrow} 1$ ㅇ leg. M. Vujić; Jadovnik: Mali Jadovnik, 17.8.2019., 1ðへ, leg. M. Vujić; Vlasina: Vlasina Rid, 24.9.2018., 1 q, leg. T. Tot; Veliki Čemernik, 20.7.2019., $2{ }^{\Uparrow} 1$ q , leg. M. Vujić, T. Tot; Mali Čemernik, 20.7.2019., 1ðð, leg. M. Vujić, T. Tot; Cvejina dolina, 25.7.2019.,

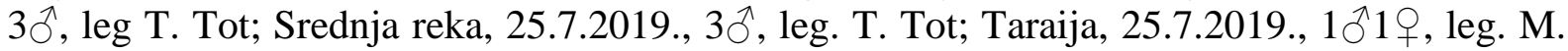
Vujić; Teskovo, 13.8.2019. leg., 1ㅇ, M. Vujić; Dejanova reka, 16.8.2019. leg., 1ठึ, M. Vujić; Plavilo 1, 3.9.2019. leg., $1 \overbrace{}^{\lambda}$, leg. I. Tot; Plavilo 2, 3.9.2019., 6ð, leg. M. Vujić; Jančin potok, 5.9.2019., 1 $\sigma^{\Uparrow}$, leg. M. Vujić; Jančini, 5.9.2019., 2ð (just observed), leg. M. Vujić; Polom, 6.9.2019., 1§̂, leg. I. Tot; Gadžini, 26.10.2019., 19, leg. I. Tot.

Notes: A. bombiforme is a species whose presence has long been known in Serbia (GlumAC, 1955) and is widespread in Europe. The species is present in Scandinavia, mountainous parts of much of Europe, including Pyrenees, Apennines, the Alps, Balkan, mountain ranges in Spain, Crete and Turkey (SPEIGHT, 2015). In Serbia A. bombiforme was recorded on mountains Kopaonik, Šar planina, Zlatar and Jadovnik (RADENKOVIĆ, 2008; MıLIČIĆ et al. 2018). At localities Jadovnik, Mali Jadovnik, Đerekare and Bijela Voda specimens were collected while feeding on Scabiosa sp. flowers in subalpine grasslands. On 
locality Đerekare, Stari Krst adults were observed in copulation which lasted a few seconds during the flight, some two meters above the ground. At the same spot noted were specimens frequently fling around Vaccinium myrtillus L. shrubs next to the stream contaminated with cow feces. At localities on Vlasina plateau specimens were mostly spotted in wetlands, marshes, at forest edges and near streams and springs. The exception is Polom, where one specimen was collected while resting on the concrete pipe transfering water from Polomska Reka river to the Vlasina Lake accumulation. A. bombiforme was recorded together with $A$. bequaerti at localities Jančin potok, Plavilo 1, Plavilo 2 and Vlasina Rid. This species may be also present on Karamanica Mt. (42.353432 22.337244) (Fig. 1F) and Sopotnica (43.289428 19.744572) where bumblebee-like hoverflies were also observed at beech forest edges but were not caught. Adults were observed feeding on flowers: Succisa pratensis Moench (Fig. 2D), Scabiosa sp. (Fig. 2E), Gentiana asclepiadea L. and Cirsium sp.

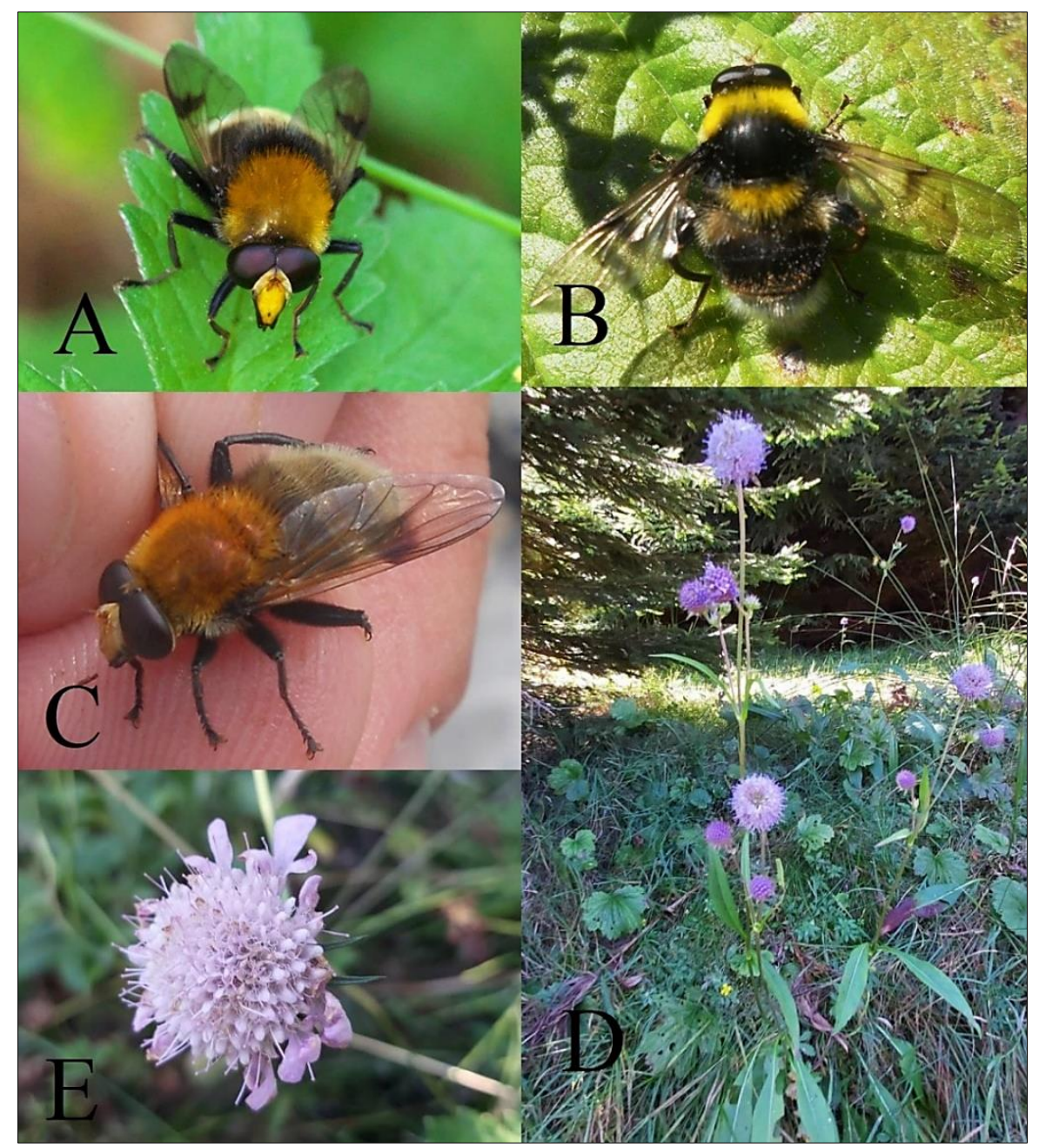

Figure 3. Habitus of Arctophila species and plants that they visit; A) Arctophila bequaerti, habitus of the male (photo by S. Ivković, 2019); B) A. bombiforme, the habitus of the male (photo by I. Tot, 2019); C) A. superbiens, habitus of the male (photo: I. Tot, 2019);

D) Succisa pratensis Moench (Caprifoliaceae) (photo by M. Vujić, 2019);

E) Scabiosa sp. (Caprifoliaceae) (photo by M. Vujić, 2019).

Arctophila superbiens (Müller, 1776) (Figs. 2C, 3C)

syn. A. mussitans (Fabricius, 1776)

Published records: RAdENKOVIĆ (2008); RADENKOVIĆ et al. (2013); MiliČIĆ et al. (2018). 
New records: Jadovnik: Ogrljača 1, 17.8.2019., 1ठ, leg. M. Vujić; Ogrljača 2, 17.8.2019., 2ð, leg. M. Vujić

Notes: A. superbiens is widespread species in Europe and its range includes Scandinavia, southward to the Pyrenees, Ireland, eastward through central and south Europe, European parts of Russia, southward from northern France. Since 1950, in Belgium and Denmark was noted a rapid decline of this species (SPEIGHT, 2015). In Serbia A. superbiens was registered only on two mountains, Kopaonik and Zlatar (RADENKOVIĆ, 2008; MiLIČIĆ et al. 2018). During this survey, A. superbiens has been registered at two localities on mountain Jadovnik (Ogrljača 1 and Ogrljača 2). Both localities are in the beech-coniferous forest, next to the road and specimens were observed resting on leaves and flying round Rubus idaeus shrubs. SPEIGHT (2015) registered that A. superbiens shows preference for pink-colored flowers, such as Succisa pratensis Moench, Scabiosa sp., Centaurea sp., Cirsium vulgare (Savi) Ten., but also feeds on white umbellifers and yellow composites, Ranunculus sp., Sonchus sp. and Rubus sp. During this fieldwork, we did not observe feeding on flowers.

Specimens were collected and observed in the second half of the year. Although SPEIGHT (2015) states that A. bombiforme and A. bequaerti occur in May and June, during fieldwork we did not record species of this genus earlier than the second half of July. The latest record in a year is that of $A$. bombiforme, registered at the end of October at locality Gadžini on Vlasina plateau. An altitude and date dependency diagram is shown in Figure 4.

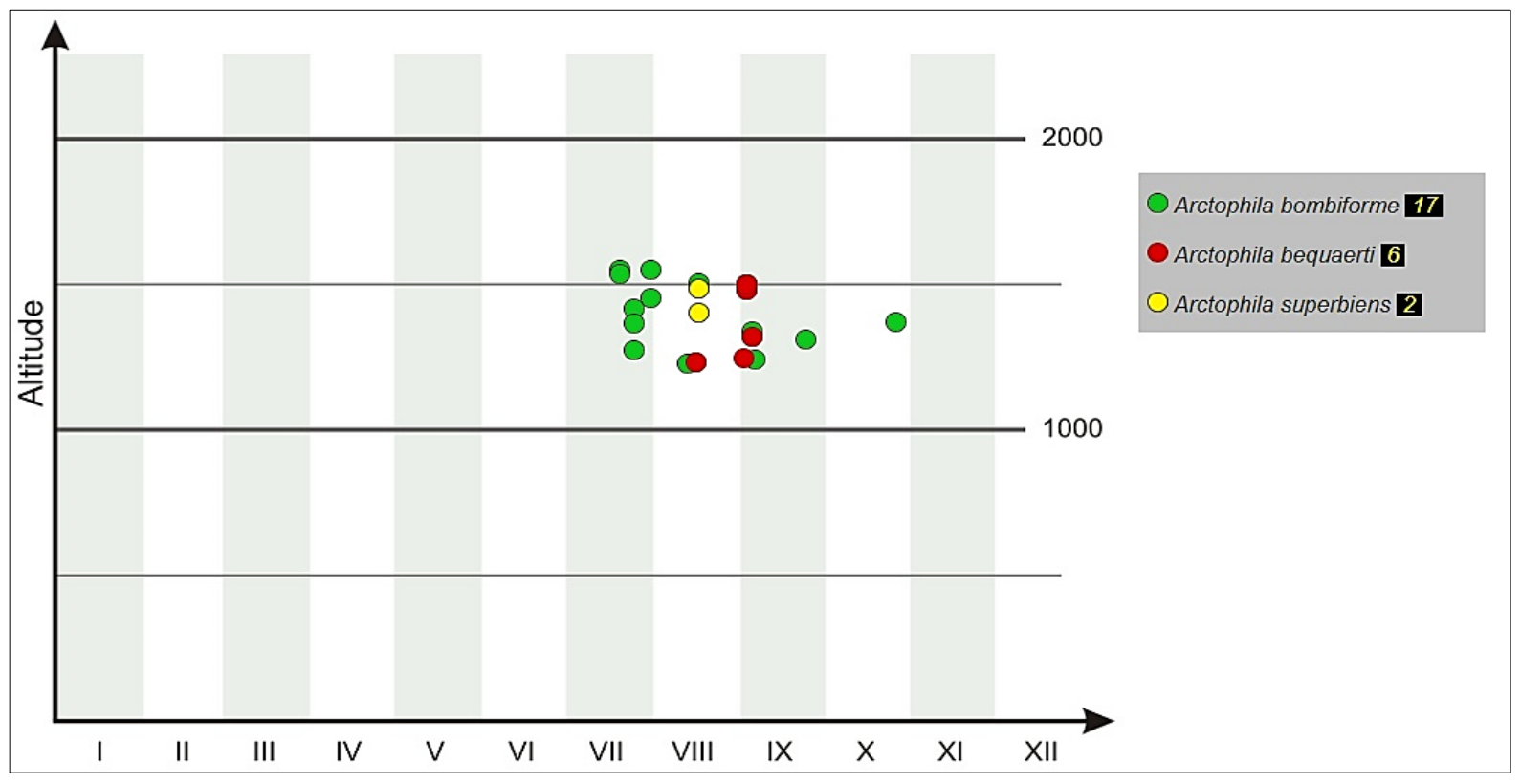

Figure 4. An altitude and date dependency diagram from the Alciphron database.

Species from genus Arctophila are considered rare in Serbia and previously were registered only on few mountains (Kopaonik, Jadovnik, Zlatar, Šar-planina) and on Vlasina plateau (GluMAC, 1955; RADENKOVIĆ, 2008; RADENKOVIĆ et al., 2013; VuJić et al., 2016; MILIČIĆ et al., 2018). A. bombiforme was the most common at studied sites. Previously conducted studies indicate the presence of this species on three mountains in Serbia: Kopaonik, Šar-planina and Jadovnik (GLUMAC, 1955; RADENKOVIĆ, 2008; RADENKOVIĆ et al. 2013; MiLIČIĆ et al. 2018). A. bombiforme was registered on the Vlasina plateau and in Đerekare for the first time. A. beqauerti was previously registered only at one locality on Vlasina plateau (Vlasina Rid) (VuJIĆ et al. 2016). During this survey, we registered this species on four localities on Vlasina plateau (Dejanova Reka, Plavilo 1, Plavilo 2, Jančin Potok), and many specimens, especially at localities Plavilo 1 and Plavilo 2, so that indicates the population on Vlasina plateau is large and stable. The data confirming the presence of A. superbiens in Serbia 
was published by RADENKOVIĆ (2008), RADENKOVIĆ et al. (2013) and MiLIČIĆ et al. (2018). This species was registered on mountains Kopaonik and Zlatar. A. superbiens was recorded for the first time on mountain Jadovnik. The distribution of species of genus Arctophila in Serbia and on Vlasina plateau is presented in Figures 5 and 6.

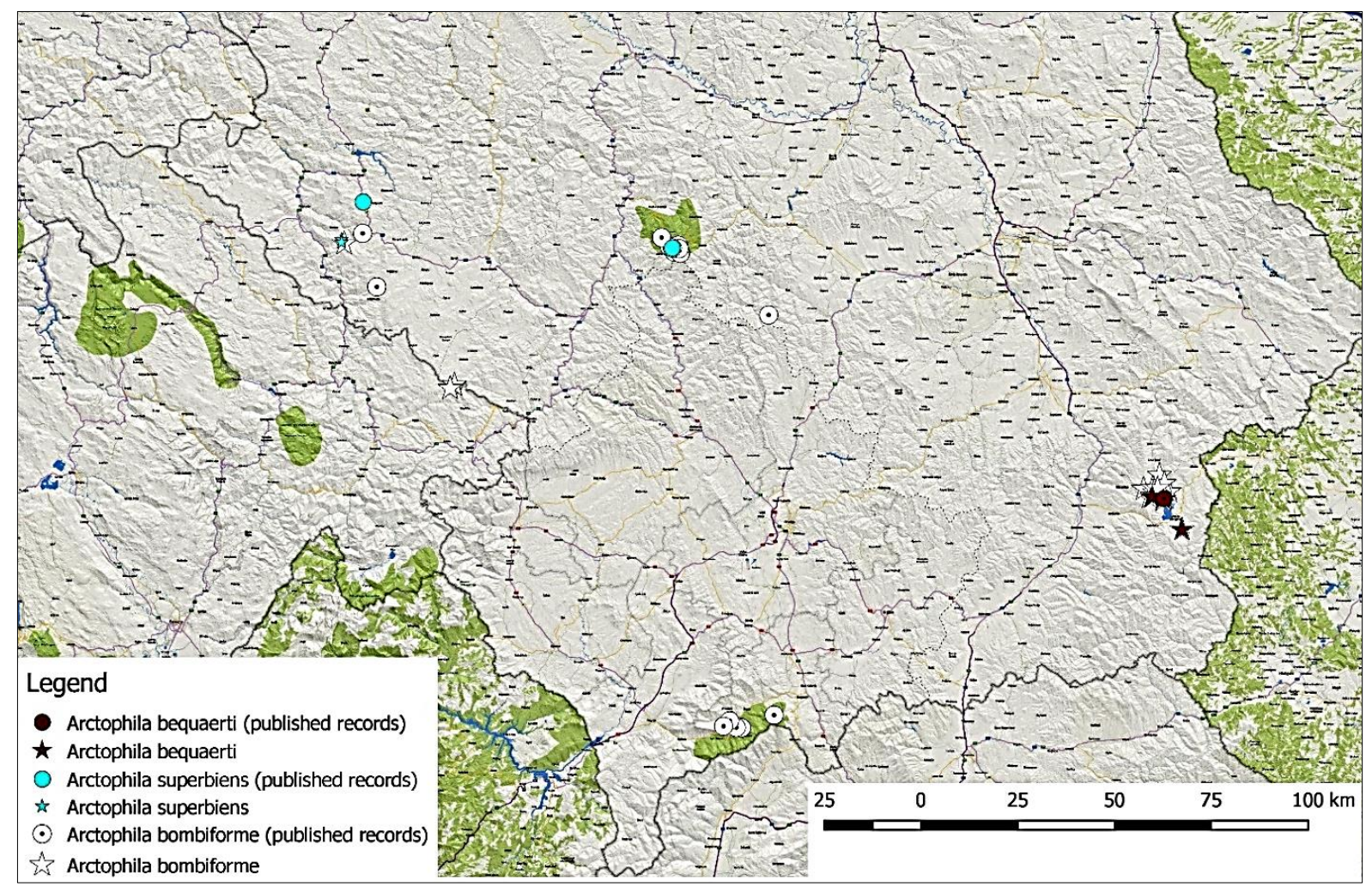

Figure 5. The distribution of species of genus Arctophila in Serbia.

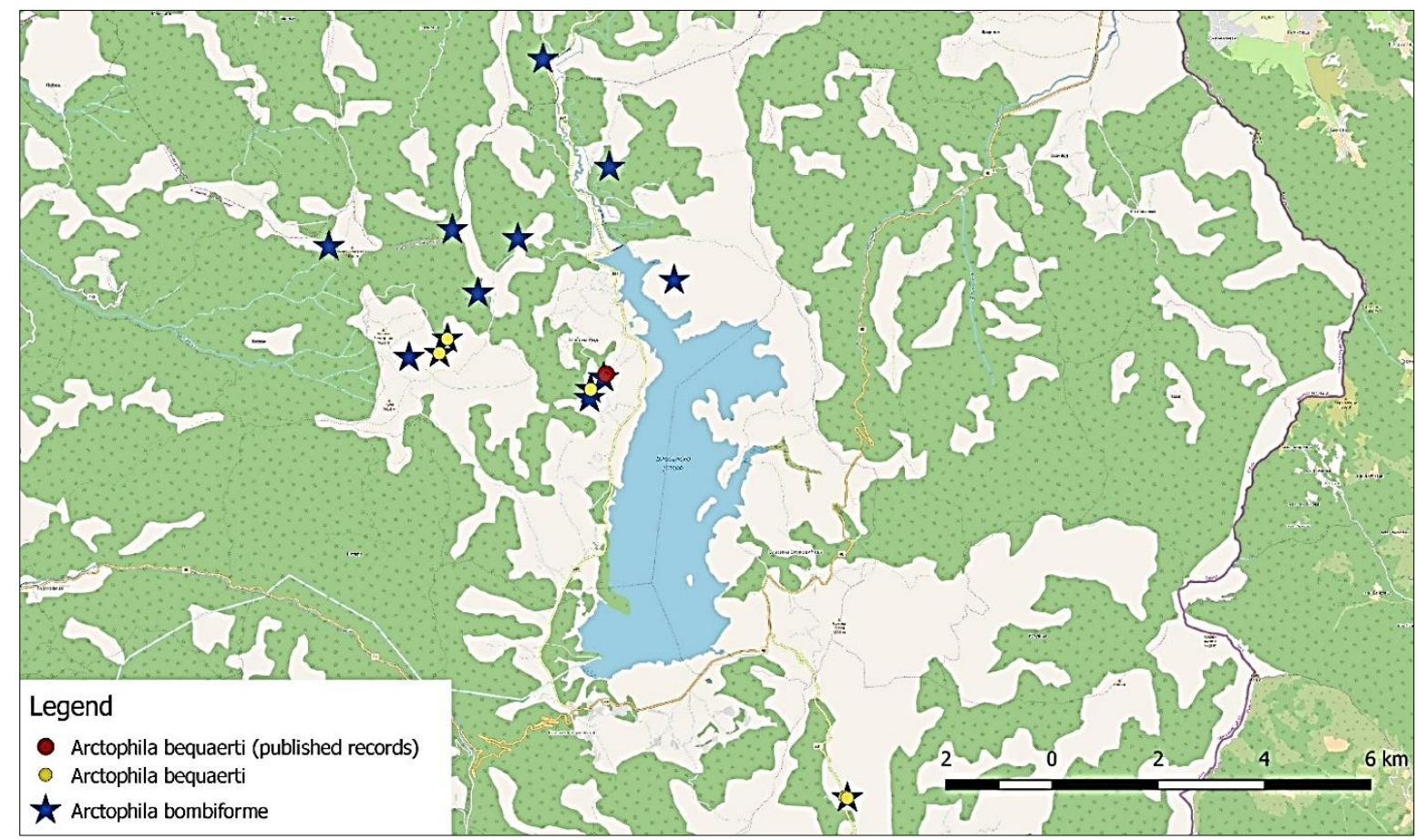

Figure 6. The distribution of species of genus Arctophila on Vlasina plateau. 


\section{Acknowledgments}

The authors are thankful to the authority of the Protected Landscape Vlasina "PE Surdulica Municipality Land Development Directorate", especially to area manager Novica Stanković, for technical support during survey realization. We are also thankful to the Scientific Research Society of Biology and Ecology Students "Josif Pančić" from Novi Sad. The other people who helped the realisation of this survey and writing of paper are Tamara Tot, Slobodan Ivković, Aleksa Maksimović, Bojana Nadaždin, Dejan Stojanović Zmaj, Slobodan Stevčić, Nemanja Marić, Semir Talović and Nataša Veljković.

\section{References:}

[1] BELIJ, S. (2014): Landscape of outstanding features Vlasina. Institute for Nature Conservation of Serbia, PE Surdulica Municipality Land Development Directorate, Belgrade, 155 pp.

[2] Đukić, A., Mirić, R., Skejo, J., RAJKov, S., Tot, I. (2019): Survey on the damselfly and dragonfly fauna (Insecta: Odonata) of the Landscape of Outstanding Features "Vlasina". Kragujevac Journal of Science 41: 133-146. doi: 10.5937/KgJSci1941133D

[3] GlumaC, S. (1955): Osolike muve Srbije (Syrphidae: Diptera) iz zbirke prirodnjačkog muzeja srpske zemlje u Beogradu (1955). Poseban otisak iz časopisa Zaštita bilja 27: 143. [In Serbian]

[4] MarkoviĆ, J., (1990): Enciklopedijski geografski leksikon Jugoslavije. Sarajevo: Svjetlost. [In Serbian]

[5] Miličić, M., Janković, M., Tot, T., Nedeljković, Z., Popov, S., IvošEvić, B., RadenKOVIĆ, S., VuJIĆ, A. (2018): New findings of hoverfly fauna (Diptera: Syrphidae) of the western part of Serbia (Zlatibor and Raška District). Acta entomologica serbica 23 (2): 43 66. doi: 10.5281/zenodo.2549536

[6] Pavićević, D., Ivković, S., Horvat, L. (2014): New and rare species of orthopteroid insects in the fauna of Serbia. Fauna Balkana 3: 103-122.

[7] Protić, LJ., NAdAžDin, B. (2019): First record of Dimorphocoris beieri Wagner 1965 (Heteroptera: Miridae) in Serbia. Acta entomologica serbica. 24 (2): 89-92. doi: $10.5281 /$ zenodo. 3552516

[8] Radenković, S. (2008): Fauna podfamilije Eristalinae (Diptera: Syrphidae) u Srbiji. Doktorska disertacija, Univerzitet u Novom Sadu, Novi Sad. [In Serbian]

[9] Radenković, S., NedeljKović, Z., RicARTe, A., Vujić, A., ŠImić, S. (2013): The saproxylic hoverflies (Diptera: Syrphidae) of Serbia. Journal of Natural History. 47: 87-127. doi: 10.1080/00222933.2012.742167

[10] RanĐElović, V.N., Zlatković, K.B. (2010): Flora and vegetation of Vlasina plateau. Niš (SRB): Faculty of Sciences and Mathematics - University of Niš, 448 pp. [in Serbian]

[11] RotherAy, G. E., GILBERT, F. (2011): The natural history of hoverflies. Forrest Text, Ceredigion, UK, 334 pp.

[12] ŠEAT, J. (2017): Contribution to the knowledge on true bugs (Insecta: Heteroptera) of Vlasina. Zaštita prirode 67 (1-2): 43-54 [in Serbian] 
[13] SKeJo, J., IVković, S. (2015): Chorthippus bornhalmi in the heart of the Balkans (Acrididae: Gomphocerinae). Articulata 30: 81-90.

[14] SpEIGHT, M.C.D. (2015): Species accounts of European Syrphidae (Diptera), 2015. Syrph the Net, the database of European Syrphidae, Syrph the Net publications, Dublin 83, 291 pp.

[15] SPEIGHT, M.C.D. (2016): Species accounts of European Syrphidae (Diptera), 2016. Syrph the Net, the database of European Syrphidae, Syrph the Net publications, Dublin 93: 288 pp.

[16] Speight, M.C.D., SARThou, J.-P. (2017): StN keys for the identification of the European species of various genera of Syrphidae 2017/Clés StN pour la détermination des espèces Européennes de plusieurs genres des Syrphidae 2017. Syrph the Net, the database of European Syrphidae (Diptera), Syrph the Net publications, Dublin 99: 139 pp.

[17] STANKOVIĆ, S., LAUŠEVIĆ, R. (1997): Lake Vlasina reservoir. In J. Blaženčić (Ed.), Vlasina Reservoir - hydrobiological studies (pp. 1-24). Belgrade: Faculty of Biology.

[18] Thompson, F. C. (2013): Syrphidae. Systema Dipterorum, Version 1.5. 13354 records. Available at: http://www.diptera.org/ Accessed 5 September 2013

[19] Tot, I., Đurić, M., Popović, M. (2017): Butterflies of Vlasina. Direkcija za građevinsko zemljište i puteve opštine Surdulica. Surdulica.

[20] Tot, I., Slacki, A., Đurić, M., Popović, M. (2015): Butterflies of the Vlasina region in southeast Serbia (Lepidoptera: Papilionoidea). Acta entomologica serbica 20: 117-135. doi: 10.5281/zenodo.45393

[21] Tot, T., Vujić, M. (2014): Alciphron - baza podataka o insektima Srbije (Diptera: Syrphidae), HabiProt http://www.habiprot.org.rs/Alciphron Accessed 18 December 2019

[22] Tot, T., Vujić, M., Likov, L., Nedeljković, Z., Radenković, S., Vujić, A. (2018): Hoverfly fauna (Diptera: Syrphidae) of the Landscape of Outstanding Features "Vlasina". Acta etomologica serbica 23: 33-50. doi: 10.5281/zenodo.1306741

[23] VAn VeEn, M. P. (2004): Hoverflies of Northwest Europe: identification keys to the Syrphidae. Utrecht: KNNV Publishing, $256 \mathrm{pp}$.

[24] Vujić, M., NedeljKović, Z., Tot, T. (2016): Arctophila bequaerti Hervé-Bazin (Diptera: Syrphidae), new to the Serbian fauna. Studia dipterologica 23 (2): 162-164.

[25] Vujić, A., RAdENKović, S., NedelJKović, Z., ŠImIć, S. (2018): A new check list of hoverflies (Diptera: Syrphidae) of the Republic of Serbia. Matica srpska Journal for Natural Sciences 135: 7-51. doi: 10.2298/ZMSPN1835007V

[26] www.qgis.org Accessed 5 January 2020 